\title{
Utilizable and Interesting Technology of the Differential Speed Rolling
}

\section{Masao NAKAMURA}

\section{1. はじめに}

異周速圧延は, 互いに周速の異なるロールを用いて圧 延することで, 興味は古く片側ロール駆動の圧延に始ま つた1). トルクバランスの関係から, 両ロールは中立点 位置が異なるので異周速になる，それら両中立点にはさ まれた領域では, せん断の様子が普通圧延と違うので圧 下力が下がる. その特徴を十分に発揮できるようにした のが異周速圧延である.この圧延はソ連においてまず興 味がもたれ2), その後わが国で積極的に研究がなされ た3) 6). 最近は一段落というところか, それらに関する 研究発表は少なくなつている.

異周速圧延に関する一般的な興味は圧下力の滅少にあ る.しかし高速側ロールの駆動トルクが普通圧延にくら べて大きいので, 圧下力の多少の減少だけでは魅力的と はいえない. また両ロールでの摩擦の方向が異なるので 圧延板がカールしやすく，すべりも大きいので表面の性 状はかならずしもよいとはいえない.したがつて, 現在 まで異周速圧延の利用実績は多くない.

筆者は, せん断変形の様子が普通圧延と異なることに 興味をもち, その変形の特徴が効果的に発揮できる加工 法について検討してきた7) 13).

そこで, 本解説は圧下力の減少効果を利用した薄板圧 延について取り上げるのではなく，筆者の研究成果を基 にして異周速圧延の未知の魅力について説明するもので ある. そのため, まず異周速圧延の圧延特性について, つぎにその特性を活かした加工法のいくつかを例にし て，その魅力的な利用法について説明する.

\section{2. 異周速压延の基本的特徵}

異周速圧延はロールの外径が同じで, 回転速度が異な る同径異周速が標準と思うが, 回転速度は同じでロール 径を変えた異径異周速もある. したがつて, 普通の圧延 機も簡単に異周速圧延機に改造でき, 異周速圧延が有効 ならば手軽にその特性を利用できる.

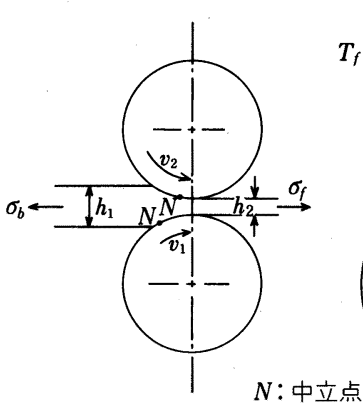

(a)

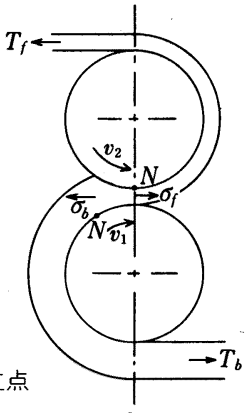

(b)
図 1 異周速圧延法の概略図

異周速圧延の特徴は，ロールと材料の速度が同じとな る中立点位置が, 普通圧延では両ロールで一致している のに対して, ロール速度が上下で異なるために一致せず, 高速ロールのほうが出口側にある（図 $1(\mathrm{a})$ ). また前方 張力 $\sigma_{f}$ がないと中立点が出口から外に出やすい. すな わち, 材料の出口速度が高速ロール速度より遅くなつて, 圧延が不安定になりやすい．理想的な異周速圧延は中立 点が高速ロール側で出口, 低速ロール側で入口に一致す ることで，PV 圧延と呼ばれている．この条件を満足す るためには, 両ロールの速度比（異速比 $v_{1} / v_{2}$ ) と圧下 率 $R$ の間につぎの関係が必要である.

$$
v_{1} / v_{2}=1 /(1-R)
$$

張力もつぎの関係が必要で, 前方張力は不可欠である.

$\sigma_{f}-\sigma_{b}=k \ln \left(h_{1} / h_{2}\right) \quad(k:$ 材料のせん断変形抵抗 $)$ 前後張力は異周速圧延では重要なので, 最適な張力条件 を容易に実現できるロールへの板の巻付けは有効である (図 1 (b)).

\section{3. ギャップ内の応カや変形状態}

普通压延の場合と比較しながら, 圧延方向と幅方向に 分けて説明する. 


\section{$3 \cdot 1$ 圧延方向}

図 2 (b) のように，両中立点にはさまれた領域は両 表面で摩擦の方向が逆なので，材料は厚さ方向全体にせ ん断変形する ${ }^{5}$. この変形はクロスシャー変形と呼ばれ ている.この領域では圧延圧力の上昇がないだけでなく， せん断応力 $\tau_{y x}$ がみかけの変形抵抗を下げるように作用 するため，摩擦が大きいほど圧延圧力は低く，したがつ て圧下力が減少する．摩擦は一般には加工荷重を上昇さ せるので，加工にとつては不都合であるが，異周速圧延 は摩擦が有効な数少ない加工例である.

圧力分布の特徵はクロスシャー領域で圧力が下がるだ けではなく，その分布が両ロールで異なることである. 図 3 は PV 条件での圧力分布を普通圧延の場合と比較 したものである7). 圧力の低下部分が高速ロール側では 入口に近く，低速ロール側では出口に近くなつている. その原因はクロスシャ一領域では摩擦の方向が逆で（図
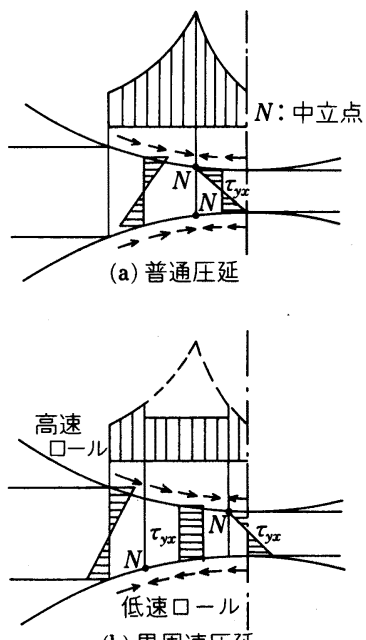

(b) 異周速圧延

図 2 ギャップ内の応力状態

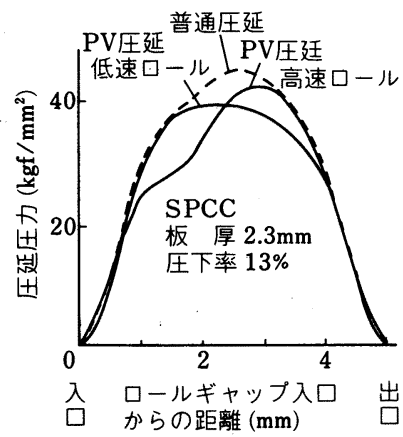

図 3 圧延圧力分布 ${ }^{7)}$
2 (b))，回転モーメントを生ずることにある.このモー メントを打ち消すように圧力分布の様子が両ロールで異 なる．両ロールで圧力分布が異なることは，変形の難易 が厚さ方向に分布していることで，入口側では高速ロー ル, 出口側では低速ロールのほうが変形しやすい.

両ロールでの圧力分布の違いは，PV 条件に近いほど 大きいが，その他圧下率が大きいほど，厚さが厚いほど 大きく，すなわち厚さ方向で変形の不均一が生じやすい 圧延条件ほど顕著である7?.クロスシャー変形による圧 下力の減少効果は，逆に圧下率が小さいほど，厚さが厚 いほど小さいことと考え合わせると，圧下力の隇少効果 が期待できない圧延条件でも異周速圧延は魅力がある.

異周速圧延での変形の特徵はクロスシャー領域にあ る. 普通圧延でのせん断応力 $\tau_{y x}$ は接触表面で摩擦応力 に等しく，厚さ中心ではゼロである（図 $2(\mathrm{a}))$. 一方異 周速圧延のクロスシャー領域は厚さ方向で一様にせん断 されるので（図 $2(\mathbf{b}))$, 厚さ中心が大きくせん断変形 する.このせん断変形は圧延材の性質に影響したり，加 工の難易にも影響するはずである．压延材の性質にはあ まり影響がないとの報告がある ${ }^{14)}$.しかし，このせん 断変形を加工に利用しようとする試みはほとんどなく， 未知の魅力がある。

\section{$3 \cdot 2$ 幅方向}

\section{$3 \cdot 2 \cdot 1$ 圧力分布 ${ }^{7)}$}

図 4 に示すように，普通圧延 $\left(v_{1} / v_{2}=1\right)$ での圧力分 布は板縁付近に圧力のピークがある.これに対して, $\mathrm{PV}$ 条件 $\left(v_{1} / v_{2}=1.15\right)$ では幅中心で圧力が下がつて, 相対的に板縁付近のピークが顕著になつたようになる. しかし，さらに異速比が大きくなつて $\left(v_{1} / v_{2}=1.3\right)$, 高速ロール側の中立点がギャップ外に出ると，圧力の ピークが下がつて, 圧力分布が平坦になる.

\section{$3 \cdot 2 \cdot 2$ 压延板の形状 ${ }^{8)}$}

図 5 は異速比による圧延板の形状の変化を示す．圧延 板の形状は急峻度に相当する伸び差率で表現した．端伸 びが大きいほどその值が大きくなる．普通圧延の場合 $\left(v_{1} / v_{2}=1\right)$ に対して, 異速比 $v_{1} / v_{2}$ が增すと伸び差率が

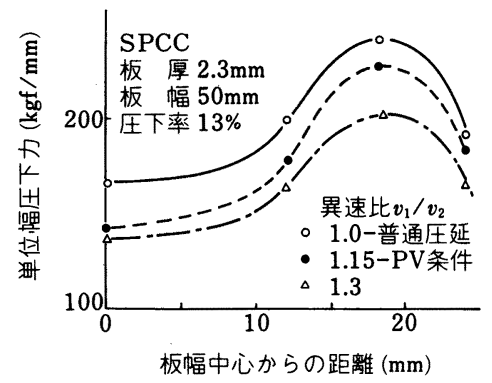

図 4 板幅方向の圧延圧力分布 ${ }^{7)}$ 

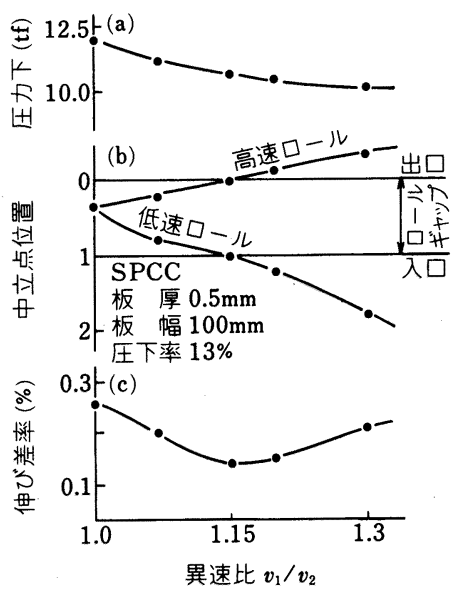

図 5 中立点位置と圧延板の形状の関係 ${ }^{8)}$

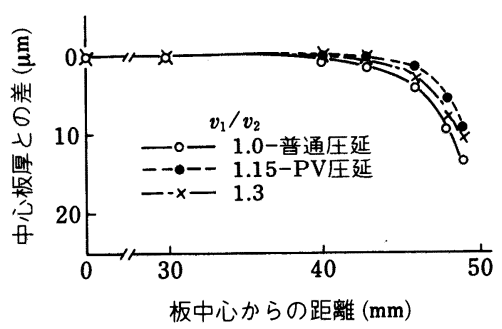

図 6 板クラウンに及ほす異速比 $v_{1} / v_{2}$ の影響 ${ }^{8)}$

小さくなつて形状がよくなる. 中立点がギャップの入口 と出口にある PV 条件 $\left(v_{1} / v_{2}=1.15\right)$ で最良であるが, それより大きな異速比になつて中立点がギャップ外に出 ると形状は悪くなる.

異速比が大きくなるにしたがつて圧延板の形状がよく なるのは, 圧下力の減少によつてロールの弾性変形が小 さくなつたためとも考えられる．しかし中立点がギャッ プ外に出ると, 圧下力はさらに滅少しているが, 板の形 状は再び悪くなつている．このことは中立点位置と板の 形状の関係が圧下力の変化だけの影響ではないことを示 している.

\section{$3 \cdot 2 \cdot 3$ 板厚分布 ${ }^{8)}$}

図 5 に対応する圧延条件での板厚分布は図 6 に示すよ うに, 普通圧延 $\left(v_{1} / v_{2}=1\right)$ の場合に対して, PV 条件 ではエッジドロップが小さくなつている，さらに大きな 異速比で中立点がギャップ外に出ると, 再びエッジド ロップが大きくなつている，この傾向は図 5 の圧延板の 形状の傾向に対応しており, 形状が悪いほどエッジド ロップが大きい.

$3 \cdot 2 \cdot 4$ 幅広がり 9
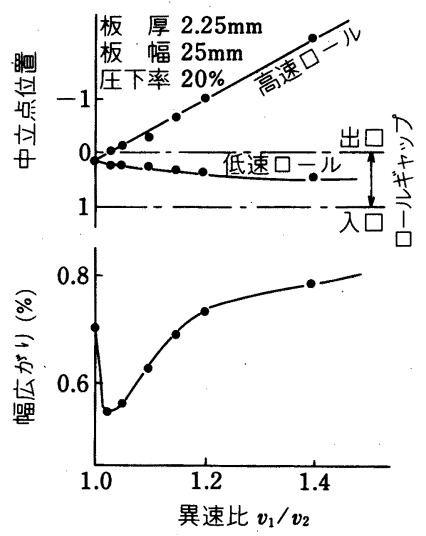

(a) 中立点位置の影響

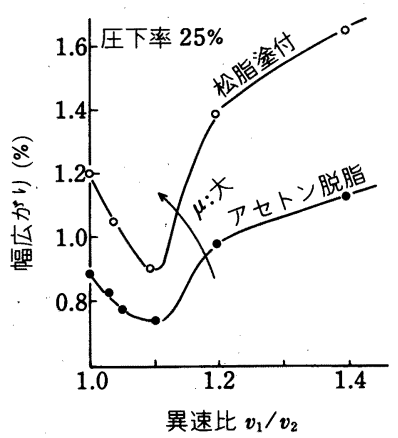

(b) 摩擦の影䈏

図 7 幅広がりの変化 ${ }^{9)}$

図 7 (a)に示すように, 中立点が出口に達するまでは, 異速比の增加とともに幅広がりは小さくなる. しかし ギャップ外に出ると急激に幅広がりが増している.この 傾向は摩擦が大きいほど顕著になる(図 7 (b)). これ らの結果は, 幅方向の変形に対する拘束が中立点位置に よつて異なることを示している.

以上のことから異周速圧延における幅方向の応力ゃ変 形挙動に中立点がいかに大きく影響しているかが理解さ れよう. 特に中立点がギャップ外に出たときのそれらの 急激な変化には興味がもてる.

\section{$3 \cdot 3$ 幅方向の变形挙漢の原因}

\section{$3 \cdot 3 \cdot 1$ 普通圧延の場合}

板圧延における幅方向変形の拘束は， 2 軸圧縮試験法 の一つである Ford 法にみられるように, 未変形部と変 形部の間のせん断応力による. 圧延の幅方向の変形を理 解するためのモデルを図 8 に示す. 幅 $(\boldsymbol{z})$ 方向の変形 挙動は未変形部を金型として, ギャップ部を変形する摩 擦 $\left(\tau_{x z}\right)$ の大きな加工と考えると理解しゃすい. 素材 
高さ $l_{d}$ が大きいほど, 変形部の応力が高いほど, 相対 的に摩擦 $\left(\tau_{x z}\right)$ の影響が小さくなるので, 幅 $(z)$ 方向 に変形しやすくなる．これを圧延に対応させると，圧下 率が大きく，ロール径が大きいほど，すなわち接触長さ $l_{d}$ が大きいほど幅広がりが大きくなる．また圧延圧力 を高くするロールとの摩擦（ $\mu$ ) が大きいほど幅広がり は大きい。これらは実際の圧延作業で経験する現象に一 致する.したがつて, 変形部と未変形部の境界（圧延で はギャップの入口, 出口) に生ずるせん断応力 $\left(\tau_{x z}\right)$ を制御できれば，幅方向の変形を大幅に変化できるが, 簡単ではない.

\section{$3 \cdot 3 \cdot 2$ 異周速圧延の場合}

中立点がギャップ内にある場合（図 $2(\mathrm{~b})$ ) は，両中 立点にはさまれたクロスシャー領域の圧力が低くなる. その分だけ圧下力は小さい。しかしギャップ入口および 出口付近の応力状態は摩擦の方向が普通圧延の場合と同 じなので，ほほ同様と考えられる．したがつて, 幅方向 のせん断応力 $\tau_{x z}$ が普通圧延の場合と同じと考えると圧 下力の減少した分だけ相対的に幅方向の拘束が強くなつ たことになる.

しかし中立点がギャップの外に出ると（図 9 ), 入口 および出口でのせん断応力 $\tau_{y x}$ が図のように変化して, 図 2 (b) と比較して板厚中心での $\tau_{y x}$ が大幅に大きくな る. したがつて板厚方向の平均せん断応力 $\bar{\tau}_{y x}$ も大きく なる.ロール入口および出口に隣接したギャップ外でも

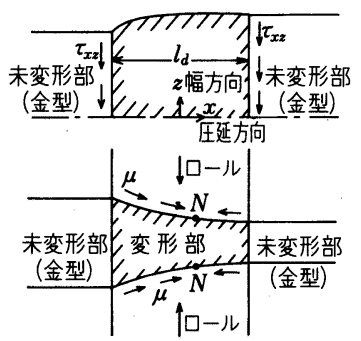

図 8 ロールギャップ部の変形モデル

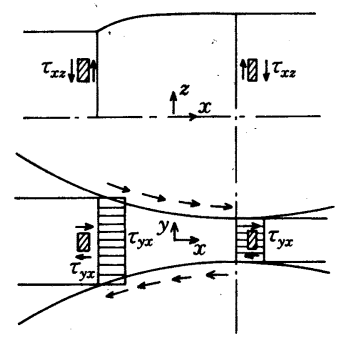

図 9 中立点がギャップ外にあるときの応力状態
塑性変形していると考えられる.そこでは $\sigma_{y}=0$ であり， $\tau_{x z}$ と $\bar{\tau}_{y x}$ だけで降伏しているとすると，

$$
\tau_{x z}=\left(\tau_{0}{ }^{2}-\bar{\tau}_{y x}{ }^{2}\right)^{1 / 2} \quad \tau_{0}: \text { せん断降伏応力 }
$$

となり， $\bar{\tau}_{y x}$ が大きいほど $\tau_{x z}$ は小さくなる．すなわち， 中立点が外に出ると幅方向の拘束は小さくなる． $\bar{\tau}_{y x}$ が 大きいほどその影響が大きいので, ロールとの摩擦 $(\mu)$ が大きいほど中立点位置の影響が大きい（図 7 (b)). 中立点位置による圧力分布, 板厚分布, 形状, 幅広がり の変化の傾向は $\tau_{x z}$ の影響として説明できる.

以上, 異周速圧延の特徵はクロスシャー領域での圧延 圧力の低下だけでなく，中立点位置によって幅方向の変 形が大幅に変化することである．幅方向の変形を大きく したい場合は，中立点をギャップ外に出せばよい．

\section{4. 異周速压延の有効な利用}

異周速圧延での变形の特徴を活かした加工法について 説明する．またギャップ内の変形が異周速圧延になる CBS 圧延についても魅力があるので取り上げる.

\section{$4 \cdot 1$ 幅方向への材料流れの利用}

中立点位置によつて, 幅方向への材料流れが変化する ことを利用するものである.

比較的幅の狭い材料の圧延で，幅広がりを小さくした い場合は，中立点がギャップ内にある異周速圧延を行え ばよい.

形圧延では製品の形状から必然的に両ロールの周速が 異なつて異周速圧延と同じ状態になる部分もあるが，そ れに注目したり，積極的に利用しようとした例はない。 しかし幅方向への材料流れが必要な形圧延では, 中立点 を皘極的にギャップ外に出した異周速圧延は魅力がある と思う。

以下，幅方向への材料流れが必要な曲げ圧延 ${ }^{15)} ゃ く$ さび形圧延 ${ }^{16)}$ に異周速圧延を適用した場合について説 明する。

\section{$4 \cdot 1 \cdot 1$ 面内曲 げ圧延 $^{9)}$}

図 10 は圧延中に幅方向に曲げ荷重を加えて, 板面内 に曲げようとするもので, 幅方向で板厚を均一にするに は曲げの内側では幅方向に伸び，外側では縮まなければ ならない。しかし圧延は板縁付近以外，幅方向に変形の ない平面ひずみ变形なので，幅の広い板を面内に曲げる ことは容易でない。このような加工条件には中立点を ギャップ外に出した異周速圧延が適当になる.

図 11 は張力のない異周速圧延によつて曲げ圧延を行 つたときの結果である．前方張力がないので低い異速比 $\left(v_{1} / v_{2}=1.05\right)$ で高速ロール側の中立点がギャップ外に 出て曲げ荷重が急激に減少して, 曲げ成形が容易になつ ている．幅中心から外側および内側の幅広がりは，中立 点がギャ.ップ外に出ると, 内側での伸びおよび外側での 縮みとも大きくなつている，さらに異速比が大きくなる とその傾向は顕著になつており, 面内の曲げ変形が容易 


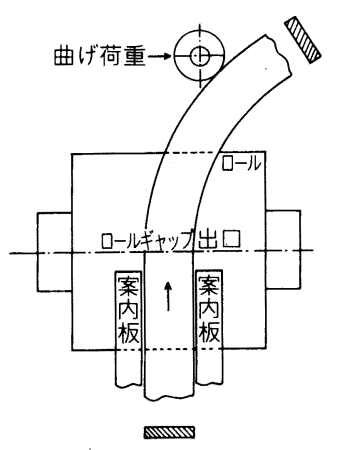

図 10 面内曲げ压延の原理 ${ }^{915)}$

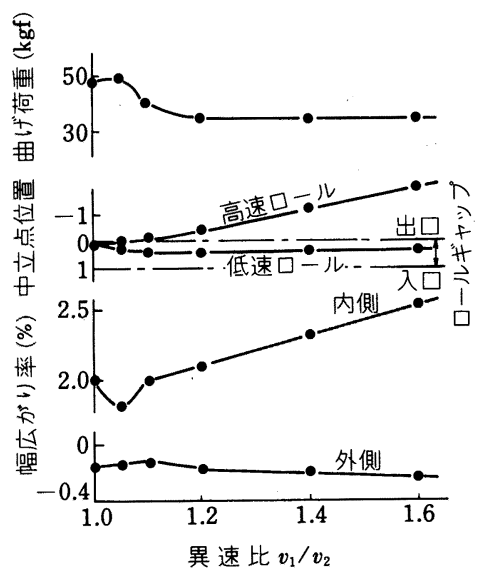

図 11 中立点位置による曲げ成形の難易 ${ }^{9)}$

に生じていることを示している.

以上，一般には困難な板面内の曲げ加工が，中立点を ギャップ外に出した異周速圧延によつて容易にできるこ とがわかる。 なお, 異周速圧延利用の効果は曲げが厳し いほど大きくなる.

$4 \cdot 1 \cdot 2$ くさび形圧延 ${ }^{9)}$

図 12 のように板厚一定の帯板を幅方向にくさび形に する加工である．平面ひずみ変形に近い圧延では拘束が なければ左側に曲がる.この曲がりを拘束して真つすぐ な帯板にするものである，そのためには，曲げ圧延と同 様に，幅方向への材料流れが必要である. すなわち，厚 肉側では縮み, 薄肉側では伸びなければならない，そこ で，異周速圧延で中立点をギャップ外に出したところ， 薄肉側, 厚肉側とも変形が大きくなつて, くさび形圧延 が容易になつた。

このように幅方向の変形を必要とする圧延には，中立 点をギャップ外に出した異周速圧延が有効といえる. し かし中立点が外に出ると, 圧延が不安定になりやすいの

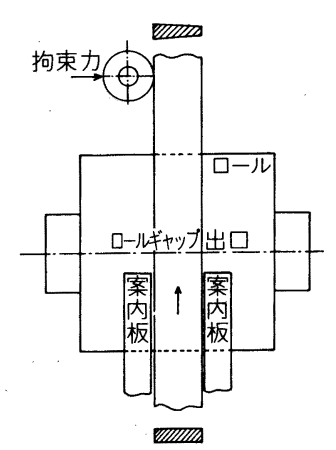

図 12 くさび形圧延の原理 ${ }^{9) 16)}$

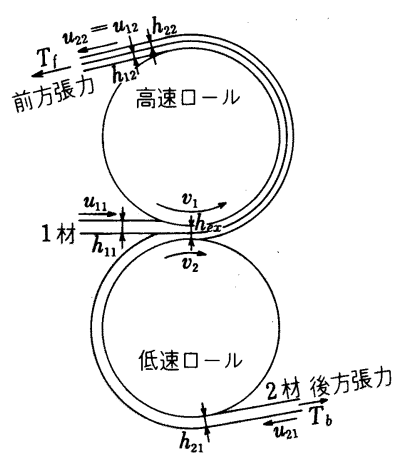

図 13 異周速圧延による接合法の原理図 ${ }^{10)}$

で, 高速ロール側の摩擦を大きくしたり, 材料の出口速 度を制御することが望ましい.

\section{$4 \cdot 2$ 厚さ中心におけるせん断変形の利用}

クロスシャー領域内の材料は厚さ中心で大きなせん断 変形を受ける. したがつて，2枚の板を同時に圧延すれ は，それらの界面はすべつて活性になるので, すべりを 利用した接合には適当である.これらの考えを基に開発 した巻付け異周速圧延によるすべりを利用した薄板の接

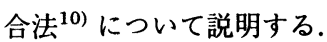

$4 \cdot 2 \cdot 1$ 異周速圧延による接合法の原理

図 13 は本接合圧延法の原理図である. 硬材 (1材) は高速ロールにのみ巻き付け, 軟材（2 材）は低速ロー ルおよび 1 材を介して高速ロールに巻き付ける. そして, 高速ロールに巻き付いた 1 材と 2 材の接合板に前方張力 $T_{f}$ を, 低速ロールに巻き付いた 2 材に後方張力 $T_{b}$ を かける. 理想とする圧延状態は, 板が両ロールの巻付け 部分ですべることなく圧延されることである. そうする と中立点は低速ロール側では入口, 高速ロール側では出 ロにある．その状態では， 2 材の圧下率 $R_{2}$ は異速比 
$v_{1} / v_{2}$ によつて一義的に定まる $\left(R_{2}=1-h_{22} / h_{21}=1\right.$ $\left.\left(v_{1} / v_{2}\right)^{-1}\right)$. 一方 1 材の圧下率 $R_{1}$ はロール間げき $h_{e x}$ との関係で定まる $\left(R_{1}=1-\left(h_{e x}-\left(1-R_{2}\right) h_{21}\right) / h_{11}\right)$.

このように両材の圧下率を設定できることは，普通圧延 による接合では圧延後のクラッド比を完全に制御できな いのに対して有利である.

ギャップ内での変形は以下のようである ${ }^{11)}$ (図 14). 2 材のほうが 1 材より圧下率が大きい. その差が大きい ほど界面でのすべりが大きく，そのすべりはギャップ入 口で最大である. ギャップ入口付近では，2 材には大き な張力 $\sigma_{2 b}$ が作用しているので，1材にくらべて極端に 変形しやすく， 2 材のみが変形する. ギャップ内部に進 むにつれて, 界面すべりによるせん断応力 $\tau_{i}$ のため, 2 材の張力は減少し, 逆に 1 材には張力が発生して, 両 材の変形しゃすさの差が小さくなる．ついには 1 材も変 形する.この状態では両材はすべることなく一緒に変形 する．そして，界面に圧延圧力が作用して接合する．接

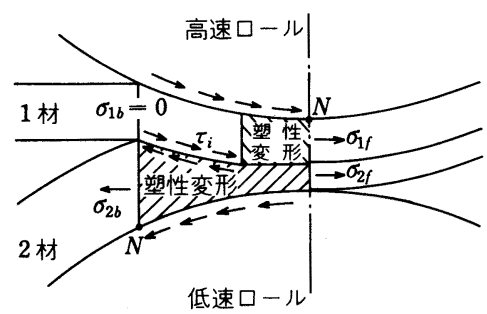

図 14 ロールギャップ内の変形状態 ${ }^{11)}$

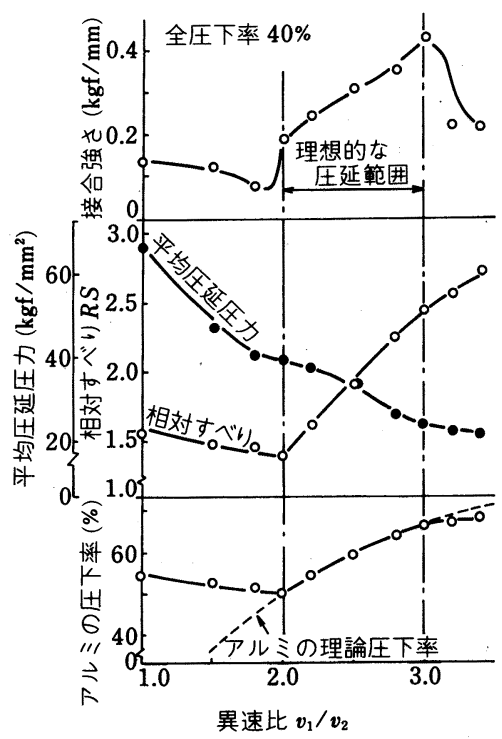

図 15 圧延状態と接合強さの関係 $\left.{ }^{10}\right)$ 合した板は高速ロールと同じ速度で出ていく．このよj なギャップ内の変形は，すべりを利用した接合としては 全く理想的である.

\section{$4 \cdot 2 \cdot 2$ 本接合法の特徴}

図 15 は異速比の影響を調べたものである. 2.0 3.0 の範囲で 2 材としたアルミニウムの圧下率が，ロールの 巻付け部で板がすべらないとして定まる理論圧下率（破 線）に一致している.この範囲で本法が理想とする圧延 状態が実現している．アルミニウムの圧下率の増加に対 応して 1 材である鋼の圧下率は隇少するので, 界面での 相対すべり $(R S)$ は異速比とともに急激に増加している. なお, 相対すべりとはギャップ入ロでの 1 材と 2 材の速 度比 $u_{11} / u_{21}$ である. この範囲では, 異速比の増加とと もに圧延圧力は低下しているが, 接合強さは著しく増加 している. 界面すべりが接合強度向上に大きく寄与して いることがわかる. なお，異速比が 3.0 より大きくな つて理想的な圧延状態でなくなると，相対すべりが大き くなつても接合強さは低下している．本法は理想的な圧 延範囲で，できるだけ相対すべりを大きくすることが適 当といえる。

本接合法は冷間で行うので，接合後の熱処理によつて 接合強度のいつそうの向上が期待できることも特徴であ る.

以上, 異周速圧延を用いたこの接合法は, 異周速圧延 での変形特性を活かしたよい例である.

\section{$4 \cdot 3$ CBS 压延 ${ }^{12) 13 \text { ) }}$}

CBS (Contact Bend Stretch) 圧延は高圧下がとれる 薄板圧延法として，25 年ほど前に提案された方法であ

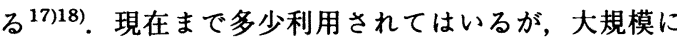
利用されていない．しかし，CBS 圧延は異周速圧延そ のものであり，圧延方法が特殊で欠点もあるが，多くの 長所があるので, それを活かせれば有効な圧延法である.

$4 \cdot 3 \cdot 1$ CBS 圧延の原理

図 16 のよjに, 周速の異なる 2 個のワークロールの 間にどこにも固定されていない小径の浮動ロールを付け る. 圧延する板をそれら 3 個のロールに巻き付けること

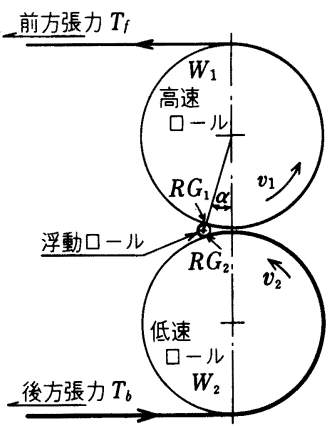

図 16 CBS 圧延法 ${ }^{12) 17}$ 
によつて, 浮動ロールの位置が決まる. 薄板は後方張力 $T_{b}$ が負荷されて，低速ロールに巻き付きながら入つて， 低速ロール側のギャップ $R G_{2}$ で圧延される. その後, 浮動ロールに巻き付きながら高速ロール側のギャップ $R G_{1}$ で圧延される. そして, 高速ロールに巻き付いて 出ていく.

本圧延法の理想は, 巻き付けられた板がロールとの間 ですべらないことである．そうすると，2 個所のロール ギャップで中立点がそれぞれ入口と出口に一致する.す なわち，両ギャップで PV 圧延になる．圧下率 $(R)$ は， ギャップ調整ではなく, $R_{i}=1-\left(v_{1} / v_{2}\right)^{-1}$ の関係でワー クロールの異速比 $v_{1} / v_{2}$ から定まる.

\section{$4 \cdot 3 \cdot 2$ 安定な圧延条件}

図 17 は前方張力による圧下率の変化を示す. ある程 度 (200 kgf) 以上の張力になると, 異速比 $v_{1} / v_{2}$ から求 まる理想的な圧下率 $\left(\boldsymbol{R}_{i}\right)$ になつている. 後方張力につ いてもまつたく同様である. それらをまとめた結果が図 18 である. 一点鎖線内の張力であれば理想的な圧下率 が得られる．異速比を一定に保ち，張力を適当な範囲に すれば, 圧延中に潤滑状態の変化, 材料の変形抵抗の変

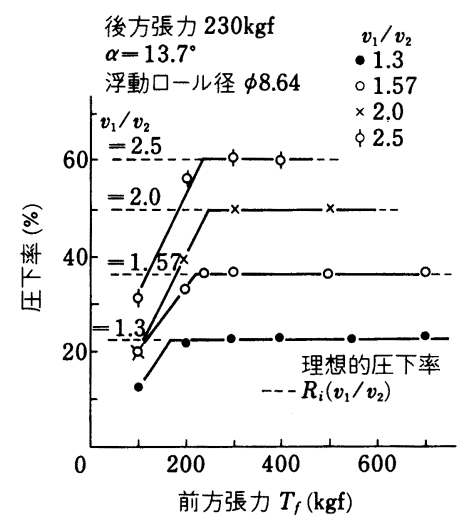

図 17 前方張力による圧下率の変化 ${ }^{12)}$

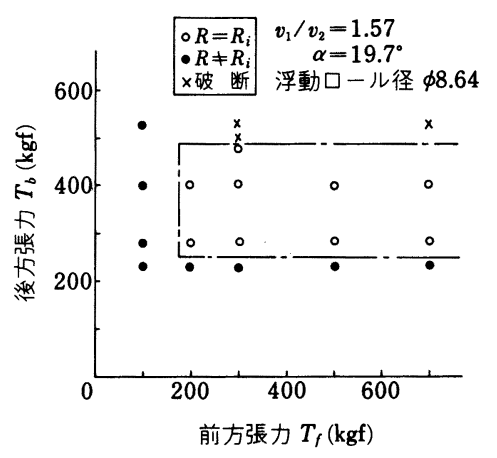

図 18 安定な圧延に心要な張力条件 ${ }^{12)}$
化，板厚の不均一などが多少生じても圧下率を一定にで きる.したがつて，圧延作業は比較的容易である。

$4 \cdot 3 \cdot 3$ 圧延特性

(1) 圧下力

図 19 は CBS 圧延での圧下力と同じワークロールを 用いた普通圧延の場合を比較したものである. CBS 圧 延の圧下力は極端に小さい。その理由は圧延が 2 個所 $\left(R G_{1}, R G_{2}\right)$ で行われ，それぞれが張力の大きな $\mathrm{PV}$ 圧延であることと, 浮動ロールが小径であるためである.

したがつて, 極薄板 (現在, ステンレス鋼で 10 数 $\mu \mathrm{m}$ ) の圧延に適し，最大圧下率も大きくできる（軟鋼，アル ミニウム，銅など延性のある材料では約 $70 \%$ ).

(2) ロールトルク

図 20 は普通圧延と比較したロールトルクの結果であ る. 小さな圧下率を除くと, 高速ロールが駆動で, 低速 ロールが制動になつている．高速ロールのトルクでも普 通圧延でのトルクより小さい.

$4 \cdot 3 \cdot 4$ 圧延材の形状特性

(1) 板厚分布

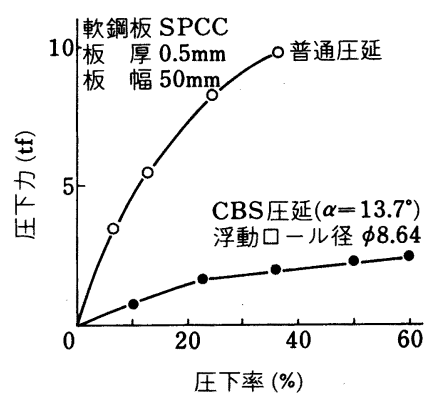

図 19 圧下力に関する CBS 圧延と普通圧延の比 較 ${ }^{12)}$

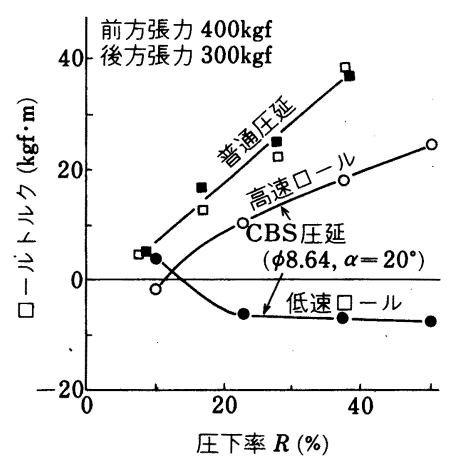

図 20 ロールトルクに関する CBS 圧延と普通圧 延の比較 ${ }^{19)}$ 


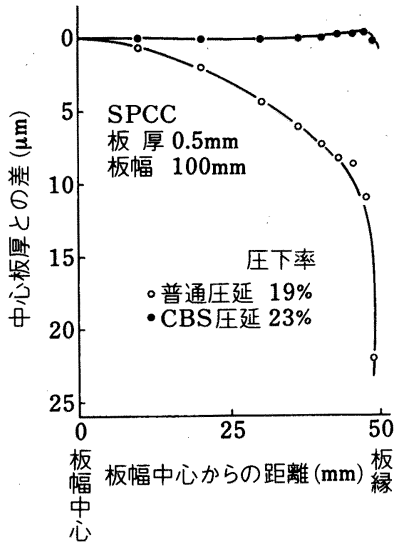

図 21 圧延板の幅方向板厚分布

図 21 は板幅方向の板厚分布について, 普通圧延と比 較したものである.CBS 圧延材は普通圧延材にくらべ て極端に板厚が均一で，特にエッジドロップが小さい． さらに板縁付近の板厚が厚くなる傾向さえある.

(2) 压延板の形状

CBS 圧延板の形状はよく，普通圧延では形状が悪く なる薄板圧延において，CBS 圧延の有効性が顕著にな る.それだけでなく形状の悪い板を圧延しても平坦な板 が得られる.このことが本圧延法のもつとも有効な特性 である. その原因は以下のようである.

形状の悪い板を圧延した場合, 後方張力は低速ロール 入口で幅方向に均一ではなく，板のつれた部分により大 きな張力が作用する.この張力が小径の浮動ロールを引 張り込んで曲げる。 その結果, より大きな張力が作用し た部分のギャップ寸法が小さくなつて，その部分での圧 下率が大きくなり，板が伸びてつれが解消する．すなわ ち平坦になる.このように浮動ロールには板の形状に対 して高い自己制御能力がある.

しかし，板がロールに巻き付いて圧延されるため，圧 延板がカールしやすい．それを防ぐには高速ロールでの 板の巻付けをはずして，パスラインを真つすぐにするの も一つの方法である.

CBS 圧延の有効性は異周速圧延の一種だから達成さ れたものであり，異周速圧延の魅力の一つである.

\section{5.おわりに}

異周速压延のような特殊加工では，その応力ゃ変形の 特徵が長所になるが，欠点にもなる. 加工としては，そ
の長所を利用するのがよいことはいうまでもないが，欠 点の原因を検討して，それを活かすように工夫すること も必要である.

異周速圧延の場合は, クロスシャー領域でのせん断の 様子が特徴である. せん断応力が圧延圧力を隇少させる ことが長所で, せん断変形が圧延板をカールさせたり, 表面性状を悪くさせることが点である．そこで，この 欠点であるせん断変形を活用する方法について検討し て, 得られた例が曲げ圧延, くさび形圧延, 接合圧延で あつた、いずれも普通圧延を用いるよりも容易に加工が できるので, 魅力ある加工法といえる.

このような工夫はまだまだ多くあると思われるので, 会員の皆様に異周速圧延に対して, いつそう興味を持た れるよう望むものである.

\section{文献}

1 ) E. SiEBEL: Archiv Eisenhüttenwes., 15 (1941), p. 125

2 ) V. N. VydRIN and L.M. AgEev: Steel in the USSR, 1 (1971), p. 295

3 ) 神居詮正, 寺門良二: 塑性と加工, 17 (1976), p. 966

4 ) 鎹田征雄, 渡辺敏夫, 片岡健二, 角南秀夫, 中川吉左衛 門: 塑性加工連合講演会講演論文集 (1978), p. 127

5 ) 中島浩衛, 河原田実, 松本紘美, 山本普康, 上堀雄司: 塑性加工連合講演会講演論文集 (1980), p. 451

6 ) 塩䗁宏行, 新谷定彦, 三上昌夫, 小出誠二: 塑性と加工, 23 (1982), p. 1080

7 ) 中村雅勇, 牧清二郎, 蔵谷雄一, 永井直記: 塑性加工春季 講演会講演論文集 $(1983)$, p. 439

8 ) 中村雅勇, 牧清二郎, 山田文洋, 永井直記: 塑性と加工, 23 (1982), p. 1223

9 ) 中村雅勇, 李 俊, 牧清二郎, 永井直記: 塑性加工春季講 演会講演論文集 (1984)，p. 155

10）中村雅勇, 牧清二郎, 松田忠明, 永井直記: 塑性と加工, 29 (1988), p. 404

11) 中村雅勇, 牧清二郎, 江崎尚和, 川井若浩: 塑性加工連合 講演会講演論文集 (1986), p. 77

12) 中村雅勇, 牧清二郎, 安部 聡, 永井直記: 塑性加工春季 講演会講演論文集 $(1982)$, p. 77

13）中村雅勇, 牧清二郎, 太田鉄也: 塑性加工春季講演会講演 論文集 $(1985)$, p. 5

14）上城太一，新谷定彦, 福富洋志: 塑性と加工, 25 (1984), p. 375

15) 戸沢康壴, 石川孝司, 三原 豊: 塑性加工春季講演会講演 論文集 (1983), p. 475

16）斉藤好弘, 新司 修, 服部泰治, 加藤健三: 塑性加工春季 講演会講演論文集 (1983), p. 373

17) L. F. CofFin, Jr.: J. Met., 19 (1967), p. 14

18) D. K. RoBertSon and D. H. SANSOME: Met. Technol., (1977), p. 365

19）中村雅勇, 牧清二郎, 安部 聡, 河口明世, 永井直記: 塑性加工連合講演会講演論文集（1983）, p. 153 